\title{
E-Service Quality Framework In A Revenue Authority Setting For South Africa
}

Madeleine Stiglingh, Ph.D., University of Pretoria, South Africa

\begin{abstract}
Tax revenue forms the backbone of any economy. The quality of the e-services provided by a revenue authority is therefore crucial, as e-service quality directly influences the burden of complying with tax obligations, and hence directly affects the tax compliance climate in a country. The aim of the study is the development of a conceptual e-service quality framework for South Africa that encapsulates the 'lens of a tax practitioner' in a revenue authority setting. In order to develop the conceptual 'lens of the tax practitioner', an in-depth, qualitative approach was used to identify a comprehensive range of attributes and determinants that potentially drive service quality in the revenue service setting. One such qualitative method is the critical incident technique, which relies on a set of procedures to collect comments on service experiences, to perform a content analysis and to classify the observations of the reported service experiences. This study proposes a theoretical e-service quality framework that encapsulates the lens of the tax practitioner' in a revenue authority setting. Findings from this study may advance the understanding and the management of the service quality of the electronic services in a revenue authority setting.
\end{abstract}

Keywords: Critical Incident Technique; E-Service Quality; South African Revenue Service; OECD

\section{INTRODUCTION}

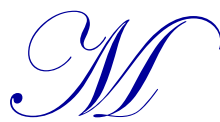

authority.

any taxpayers who have had dealings with the tax authorities in the past would probably be sceptical, and in the words of Croome (2006), they would believe that there can be peace in the Middle East before they could imagine a world where they receive quality services from a tax

Nevertheless, the Organisation for Economic Co-operation and Development ${ }^{1}$ (OECD, 2010a) has confirmed that they are committed to improving the quality of taxpayer services. The vision for the improvement of service quality is also extended to tax practitioners as the OECD (2008) believes that alliances with these intermediaries may be crucial to challenging community attitudes and influencing taxpayer behaviour and might allow for an integrated approach to addressing compliance issues. South Africa has been offered enhanced engagement with the OECD, but improved taxpayer (including tax practitioners) services might be one of the OECD standards that would be evaluated to determine whether South Africa would be eligible for future membership (OECD, 2011).

The South African Revenue Service (SARS) gave momentum to their service quality journey with the launch of a modernisation agenda in the 2007/2008 financial year. The aim of this modernisation agenda is to enhance SARS's use of Information and Communication Technologies (ICTs) to make SARS a world-class revenue authority. SARS embarked on a programme to transform the income tax process from a complex paper-based,

\footnotetext{
${ }^{1}$ The OECD originated in 1960, when 18 European countries plus the USA and Canada joined forces to create an organisation dedicated to global development. Today, the OECD's 34 member countries span the globe, from North and South America to Europe and the Asia-Pacific region. Member countries include many of the world's most advanced countries but also emerging countries like Mexico, Chile and Turkey. The OECD also works closely with emerging giants like China, India and Brazil and developing economies in Africa, Asia, Latin America and the Caribbean (OECD 2011).
}

2013 The Clute Institute http://www.cluteinstitute.com/ 
labour-intensive process to a simplified automated electronic one (e-services). The reason for this endeavour was twofold: to reduce the costs of meeting income tax obligations for SARS and taxpayers alike and to enhance SARS's ability to ensure taxpayer compliance (SARS, 2010a). Oupa Magashula (2010), the Commissioner of SARS, also confirmed the importance of service quality in SARS's interactions with tax practitioners ${ }^{2}$ and emphasised that SARS and the tax practitioners should be able to understand the world from each other's perspective.

Only a limited number of studies have contributed to the understanding of the e-service quality world from the taxpayers' perspective. These studies do, however, not fully encapsulate the e-service quality perspective of a tax practitioner in a tax authority setting (Barnes and Vidgen, 2007; Connolly and Bannister, 2008; Hu et al., 2009; Hwang, 2000; Rotchanakitumnuai, 2008).

In order to encapsulate the e-service quality perspective of a tax practitioner in a tax authority setting, an in-depth, qualitative approach using the critical incidence technique was required to identify a comprehensive range of attributes and determinants that potentially drive e-service quality in the revenue authority industry and setting. These determinants were ordered in an e-service quality framework and - as suggested by Johnson and Gustafsson (2000:47) - they represent the 'lens of the tax practitioner'.

Building the 'lens of the tax practitioner' is justified as it is estimated that tax practitioners represent approximately 4 million of the 6.3 million South African taxpayers (SARS, 2007; Snyckers, 2006). Robledo (2001) states that understanding 'the lens of the customer' is a prerequisite for delivering superior service, since customers (in this case tax practitioners) evaluate e-service quality by comparing their perceptions of the service with their expectations. When SARS knows the e-service quality determinants relevant to the tax practitioners, it becomes possible to identify how to manage e-service quality (Gaster and Squires, 2003; Grönroos, 1988; Palfrey et al., 1992; Philip and Hazlett, 1997; Seth et al., 2005). Better service quality management of the e-services rendered to tax practitioners might also influence taxpayer behaviour and would allow for an integrated approach to addressing compliance issues. Oberholzer (2008) recently found that non-compliance by taxpayers is one of the main causes for the significant gap between the amount of tax theoretically collectable from economically active persons and that actually collected in South Africa. An e-service quality framework is justified, because it is an essential means of improving the e-services of SARS and therefore also improving voluntary compliance.

To enhance the understanding of the 'lens of the tax practitioner', this article commences with a literature review of the studies relevant to the e-service quality of SARS. Thereafter the research methodology followed in this research is discussed. The proposed e-service quality framework is presented, followed by the conclusion.

\section{LITERATURE REVIEW}

In the review of the literature, the related theoretical aspects relevant to this study are discussed. Firstly, the meaning of quality and service quality are clarified. Secondly, the theoretical constructs underpinning service quality are explored and to contextualise this study, the reported service quality literature in a revenue authority setting is summarised.

Quality can be defined in various ways. The user-based approach starts with the premise that quality is not an objective thing, but is 'in the eyes of the beholder' (Berry et al., 1985; Garvin, 1984; Philip and Stewart, 1999). The concept is therefore subjective, hinging on customers' individual perceptions. The quality of a service is judged to be high when customers say it is (Berry et al., 1988; Grönroos, 1988; Gummesson, 1992; Juran, 1988:5; Schneider and White, 2004). The user-based approach to quality was predominantly used in this study, since SARS states that it wishes to focus on service delivery (SARS, 2010b) and the nature of service delivery makes it particularly appealing as the focus of an approach to defining quality in the realm of services (Schneider and White,

\footnotetext{
${ }^{2}$ From SARS's perspective, the term 'tax practitioner' refers to and includes any person giving advice to any other person in respect of an Act administered by the Commissioner, or who, for reward, completes or assists with the completion of any document to be submitted to the Commissioner (section 67A of the Income Tax Act, Act 58 of 1962).
} 
2004). Boothe (1990) summarises the importance of this approach as follows: 'In the uncertain world of providing services, one thing is certain: the customer [being the tax practitioner] defines quality.'

It is widely agreed that service quality depends on two variables: expected (desired) service and perceived service. Perceived service quality is the outcome of an evaluation process where the expected service is compared with the service received (Parasuraman et al., 1985). Service quality is defined mainly by means of service quality models (Dabholkar et al., 2000; Grönroos, 1984, 1988; Gummesson, 1992; Kang and James, 2004; Parasuraman et al., 1985; Parasuraman et al., 1988). It is also acknowledged that service quality is a multidimensional, hierarchical construct, which means that customers form their service quality perceptions on the basis of their evaluation of performance at multiple levels (Brady and Cronin, 2001; Dabholkar et al., 2000; Grönroos, 1984, 1988; Gummesson, 1992; Kang and James, 2004; Parasuraman et al., 1985, 1988).

Most of the frameworks and models proposed in the aforementioned studies were not performed in an eservice setting. Many researchers have also found that e-service quality is influenced by determinants that differ from traditional service quality (Cox and Dale, 2001; Santos, 2003; Zhu et al., 2002; Zeithaml et al., 2002).

Various qualitative studies have been conducted on different aspects of the e-service quality construct. Madu and Madu (2002) and Santos (2003) have identified service determinants for e-service quality in general. By contrast, Buckley (2003) and Lind et al. (2007) have identified and proposed an alternative model to evaluate eservices in the public sector. Lee and Lin (2005), Vos (2003) and Zhu et al. (2002) have adjusted existing traditional service quality instruments, specifically SERVQUAL, which was developed by Parasuraman et al. (1986), Parasuraman et al. (1988) and Parasuraman et al. (1991) to evaluate e-service quality in the e-service environment.

Other researchers have proposed specific general quantitative e-service quality instruments and have also developed and tested their proposed scales for measuring e-service quality (Christobal et al., 2007; Parasuraman et al., 2005; Wolfinbarger and Gilly, 2003; Yang et al., 2004; Zhang and Prybutok, 2005).

As SARS falls within the public sector domain, the numerous service quality models developed specifically for e-government might also be relevant to this research. However, the normal e-government service quality models would not necessarily meet the requirements of revenue authorities, as the e-services used in the tax environment are more complex than those used in most other e-government services (Arkinci et al., 2010). The studies relevant to this research are therefore those that were performed in a tax authority e-service environment.

The first reported e-service quality study in a tax authority setting was done by Hwang (2000) who did not develop a new service quality model, but performed closed-ended question surveys in the tax agency environment which focused on citizens' technology acceptance and sought ways to encourage citizens' adoption of e-government services.

Barnes and Vidgen (2007) later examined the quality of the website of the Inland Revenue of the UK government, using an existing general service quality model, the E-Qual method (previously called WebQual). Although rich qualitative data was generated from their open-ended questions, they used the qualitative data mainly to triangulate the quantitative results.

Connolly and Bannister (2008) slightly adjusted the general multi-item scale that was developed by Parasuraman et al. (2005) to assess e-service quality (E-S-Qual) in order to evaluate the e-service quality of the Irish tax collection agency. They based their choice of a measuring instrument on a literature review they conducted; then they adjusted the E-S-Qual instrument with input from the revenue agency itself. Apart from the fact that E-S-Qual is deemed to evaluate services from the customers' perspective, no research has hitherto been conducted to verify whether this measuring scale fully encapsulates the 'lens of the customer' in a tax collection agency environment.

Hu et al. (2009) built and tested a service quality model identifying the determinants of service quality of online tax services in Hong Kong. However, the model does not identify the details of the service attributes required to develop a survey instrument. It was also built from an extensive review of existing service quality models and might therefore not fully encapsulate the 'lens of the customer' in a tax collection agency environment. 
Rotchanakitumnuai (2008) developed the E-GOVSQUAL-RISK model after interviewing a small sample of 30 individual taxpayers in Thailand. This is the only qualitative study in a tax collection agency environment to date. Given that Donnelly and Shiu (1999) suggest that culture may influence service quality perceptions, the study conducted in the Asian region may not necessarily be applicable to the African continent. The interviews were semistructured interviews, which may also have resulted in the inclusion of service quality aspects that would not necessarily represent the 'lens of the customer'. This model was based on the views of a small sample of individual taxpayers - other types of taxpayers, such as corporates, were not represented. Nomdoe and Pather (2007) also found that different stakeholders tend to evaluate services on different levels - this limits the applicability of Rotchanakitumnuai's (2008) study to the present study, which focuses on the views of tax practitioners, and not those of individual taxpayers.

No study has been published thus far that fully encapsulates the 'lens of the customer' in a tax collection agency setting. The research methodology to develop a conceptual e-service quality framework that represents the 'lens of the tax practitioner' is presented next.

\section{RESEARCH METHODOLOGY}

In order to develop the specific 'lens of the tax practitioner' needed to evaluate the e-services that SARS renders, an in-depth, qualitative approach was used to identify a comprehensive range of attributes and determinants that potentially drive service quality in the revenue service industry and setting, as suggested by Johnson and Gustafsson (2000) and Ladhari (2010). One such qualitative method is the critical incident technique, which relies on a set of procedures to collect comments on service experiences, perform a content analysis and classify the observations of service experiences. The critical incident technique was chosen because the evaluation of a tax practitioner's perceptions of the service quality of SARS:

- $\quad$ is a relationship-oriented assessment of service quality (Odekerken-Schröder et al., 2000);

- $\quad$ is carried out by the customers (tax practitioners) (Bitner, 1990; Odekerken-Schröder et al., 2000);

- $\quad$ is carried out in the business-to-customer context (Gremler, 2004);

- $\quad$ seeks to provide the answer to a question in the service research environment (Gremler, 2004); and

- $\quad$ is measured where the user-based approach of quality has been identified as the most suitable approach to apply (Johnson and Gustafsson, 2000; Parasuraman et al., 1985).

The critical incident data were collected by means of open-ended questionnaires which tax practitioners who were registered with SARS in terms of section 67A of the Income Tax Act (Act No 58 of 1962) were asked to complete. The respondents were asked to evaluate the service quality of SARS as perceived by the tax practitioners in all interactions with SARS.

The total population of approximately 17000 tax practitioners returned 811 completed questionnaires, which represents a response rate of approximately $5 \%$. This response rate may be considered satisfactory, because the average response rate for questionnaires in marketing-related studies is often as low as 5\% (McDaniel and Gates, 1996, cited in Odekerken-Schröder et al., 2000) and because the purpose of open-ended questions is to assist in an exploratory study. Gremler (2004) found that the average number of responses in 115 critical incident technique studies was 341. In the current study, the 811 responses received may therefore be considered to be adequate.

The data analysis involved three processes. The first was the identification of usable critical incidents; the second was the development of a classification scheme for the content analysis and the third was a content analysis of the identified critical incidents.

The analysis procedure advocated by Flanagan (1954) indicates that the critical incident itself is the basic unit of analysis. Hence, for the purposes of the research reported in this article, critical incidents were defined as standalone positive and negative e-service experiences by tax practitioners of the services provided by SARS. Only critical incidents as defined were used in the data analysis. From the 811 responses, 5416 critical incidents relating to the service quality of SARS were identified. Of these, 1284 critical incidents related to the e-services of SARS and were analysed. Gremler (2004) reported that the average number of usable critical incidents across 115 critical incident technique studies was 443. In the current study, many more critical incidents than the average number of 
443 usable critical incidents were identified and it can therefore be concluded that the number of critical incidents identified was indeed high enough to draw a relevant conclusion.

The critical incidents that were identified were classified into a self-developed classification framework. The classification framework was originally derived from a synthesis of the available literature, but adapted as the classification of the critical incidents proceeded. The critical incident technique was thus used in this study both to confirm service quality aspects identified in the literature review and to assist in the development of a new e-service quality framework.

The analysis of the critical incidents and their categorisation into the classification scheme was performed by the researcher and nine research assistants. The research assistants were thoroughly trained, and each critical incident was independently classified by at least three but mostly four different persons. It is reasonable to assume that the thoroughness of the process, as well as the interjudge agreement of more than $80 \%$, should indicate that the results of the content analysis - as presented next - were reliable.

\section{RESEARCH RESULTS}

The classification scheme used for the content analysis of the critical incidents acknowledged that service quality is a multidimensional, hierarchical construct, which means that customers form their service quality perceptions on the basis of their evaluation of performance at multiple levels. The lowest level (level 1) is the evaluation of various service attributes, the second level is referred to as service determinants (level 2) and the highest level is the evaluation of different service dimensions (level 3).

The service attributes (level 1) relevant to this research were identified from a detail content analysis of all the critical incidents (refer to paragraph 4.1). A critical incident of for example the fact 'that there is no electronic function for the registration for certain taxes' or 'it is nice to download all the tax forms from the website' would be classified under what was identified as the 'scope of e-services offered' service attribute. After the identification of the relevant service attributes, the service attributes were classified under the e-service quality determinants (level 2 - refer to paragraph 4.2). The e-service quality determinants were derived from the literature review, but adapted and specifically defined for the purpose of this research. The different service determinants were classified into the different e-service quality dimensions (level 3 - refer to paragraph 4.3) identified by Parasuraman et al. (2005).

\subsection{Service attributes}

The content analysis of the critical incidents identified various service attributes (level 1). The number of the critical incidents allocated to the different service attributes is used as an importance indicator. The service attributes are listed in Table 1.

Apart from the general responses, it was found that the scope of the e-services offered by SARS $(14.64 \%$ of responses) is the most important service attribute when the e-service quality of SARS is evaluated. This service attribute indicated that the tax practitioners either required additional e-service offerings or showed appreciation for the fact that the scope is enhanced to include certain aspects. The scope of the e-service attribute also included those service aspects that related to the completeness of the website.

The second most important service attribute appeared to be the speed of the service performance service attribute $(11.53 \%)$ that relates to the turnaround time of the business processes of SARS. This refers to the time from for example the submission of an electronic tax return until the receipt of a tax assessment.

The time-saving service attribute that refers to the convenience of having a quicker, more productive interaction platform with SARS was found to be the third most important service quality service attribute (10.83\%).

The accurate service delivery service attribute (9.5\%) could be regarded as the fourth most important service attribute for evaluating the e-service quality of the services provided by SARS. It refers to the accuracy of the outcome of business processes as well as the accuracy of the assistance provided when required. 
The ease of use of the e-services was the only other service attribute that attracted more than $5 \%$ of the responses and relates to the user-friendliness of the e-services of SARS.

Table 1: Service attributes for 'lens of the tax practitioner'

\begin{tabular}{|c|c|c|c|c|}
\hline Service attribute & $\begin{array}{c}\text { Positive } \\
(\mathrm{n}=\text { total for attribute) }\end{array}$ & $\begin{array}{c}\text { Negative } \\
(\mathrm{n}=\text { total for attribute) }\end{array}$ & Total & $\begin{array}{c}\text { Percentage }(\%) \\
n=1284\end{array}$ \\
\hline General & $\begin{array}{c}221 \\
89.47 \% \\
\end{array}$ & $\begin{array}{c}26 \\
10.53 \% \\
\end{array}$ & 247 & $19.24 \%$ \\
\hline Scope of services offered & $\begin{array}{c}83 \\
44.15 \% \\
\end{array}$ & $\begin{array}{c}105 \\
55.85 \%\end{array}$ & 188 & $14.64 \%$ \\
\hline Speed of service performance & $\begin{array}{c}89 \\
60.14 \%\end{array}$ & $\begin{array}{c}59 \\
39.86 \%\end{array}$ & 148 & $11.53 \%$ \\
\hline Time saving & $\begin{array}{c}110 \\
79.14 \% \\
\end{array}$ & $\begin{array}{c}29 \\
20.86 \% \\
\end{array}$ & 139 & $10.83 \%$ \\
\hline Accurate service delivery & $\begin{array}{c}67 \\
54.92 \% \\
\end{array}$ & $\begin{array}{c}55 \\
45.08 \% \\
\end{array}$ & 122 & $9.50 \%$ \\
\hline Ease of use & $\begin{array}{c}79 \\
90.80 \%\end{array}$ & $\begin{array}{c}8 \\
9.20 \% \\
\end{array}$ & 87 & $6.78 \%$ \\
\hline Pre-testing & $\begin{array}{c}0 \\
0.00 \%\end{array}$ & $\begin{array}{c}52 \\
100.00 \%\end{array}$ & 52 & $4.05 \%$ \\
\hline Knowledge and skills of employees & $\begin{array}{c}15 \\
30.61 \% \\
\end{array}$ & $\begin{array}{c}34 \\
69.39 \% \\
\end{array}$ & 49 & $3.82 \%$ \\
\hline Crash and freeze problems & $\begin{array}{c}0 \\
0.00 \% \\
\end{array}$ & $\begin{array}{c}47 \\
100.00 \% \\
\end{array}$ & 47 & $3.66 \%$ \\
\hline Organisation & $\begin{array}{c}16 \\
35.56 \% \\
\end{array}$ & $\begin{array}{c}29 \\
64.44 \% \\
\end{array}$ & 45 & $3.50 \%$ \\
\hline Electronic filing system & $\begin{array}{c}32 \\
84.21 \% \\
\end{array}$ & $\begin{array}{c}6 \\
15.79 \% \\
\end{array}$ & 38 & $2.96 \%$ \\
\hline Reduction of effort & $\begin{array}{c}26 \\
89.66 \% \\
\end{array}$ & $\begin{array}{c}3 \\
10.34 \% \\
\end{array}$ & 29 & $2.26 \%$ \\
\hline When I want it & $\begin{array}{c}20 \\
86.96 \% \\
\end{array}$ & $\begin{array}{c}3 \\
13.04 \% \\
\end{array}$ & 23 & $1.79 \%$ \\
\hline Waiting time & $\begin{array}{c}2 \\
12.50 \%\end{array}$ & $\begin{array}{c}14 \\
87.50 \% \\
\end{array}$ & 16 & $1.25 \%$ \\
\hline Speed of launching the site and pages & $\begin{array}{c}2 \\
13.33 \% \\
\end{array}$ & $\begin{array}{c}13 \\
86.67 \% \\
\end{array}$ & 15 & $1.17 \%$ \\
\hline Ease of finding information & $\begin{array}{c}2 \\
15.38 \%\end{array}$ & $\begin{array}{c}11 \\
84.62 \%\end{array}$ & 13 & $1.01 \%$ \\
\hline Cost saving & $\begin{array}{c}9 \\
81.82 \% \\
\end{array}$ & $\begin{array}{c}2 \\
18.18 \%\end{array}$ & 11 & $0.86 \%$ \\
\hline Protection of personal information & $\begin{array}{c}8 \\
88.89 \% \\
\end{array}$ & $\begin{array}{c}1 \\
11.11 \% \\
\end{array}$ & 9 & $0.70 \%$ \\
\hline Where I want it & $\begin{array}{c}6 \\
100.00 \% \\
\end{array}$ & $\begin{array}{c}0 \\
0.00 \% \\
\end{array}$ & 6 & $0.47 \%$ \\
\hline Speed of performing the service & $\begin{array}{c}3 \\
50.00 \% \\
\end{array}$ & $\begin{array}{c}3 \\
50.00 \% \\
\end{array}$ & 6 & $0.47 \%$ \\
\hline Willingness of employees & $\begin{array}{c}3 \\
50.00 \% \\
\end{array}$ & $\begin{array}{c}3 \\
50.00 \% \\
\end{array}$ & 6 & $0.47 \%$ \\
\hline Incentive & $\begin{array}{c}3 \\
60 \% \\
\end{array}$ & $\begin{array}{c}2 \\
40 \% \\
\end{array}$ & 5 & $0.39 \%$ \\
\hline $\begin{array}{l}\text { Protection of tax practitioners from personal } \\
\text { liability }\end{array}$ & $\begin{array}{c}3 \\
100.00 \%\end{array}$ & $\begin{array}{c}0 \\
0.00 \%\end{array}$ & 3 & $0.23 \%$ \\
\hline
\end{tabular}

The knowledge and skills of the employees of SARS attracted less than 5\% of the responses $(3.82 \%)$ and relate to the ability of the staff of SARS to assist the tax practitioner with the e-services. Given the fact that not all the respondents would have required the assistance services, this service attribute may also be regarded as being important for evaluating the e-service quality of SARS. 


\subsection{Service determinants}

The service attributes presented above were clustered into different e-service determinants (level 2). The eservice determinants were derived from the literature review, but adapted and specifically defined for the purpose of this research. The following e-service determinants were found to be relevant in building the 'lens of the tax practitioner', namely fulfilment, convenience, efficiency, system availability, reliability, assurance, empathy, responsiveness, security and incentive. The definitions and number of responses per service determinant are presented in Table 2.

Table 2: Service determinants for the 'lens of the tax practitioner'

\begin{tabular}{|c|c|c|}
\hline $\begin{array}{c}\text { Service } \\
\text { Determinant }\end{array}$ & $\begin{array}{l}\text { Percentage \% } \\
(\mathrm{n}=1284)\end{array}$ & Definition \\
\hline Fulfilment & 31.31 & $\begin{array}{l}\text { The outcome of the service (the extent to which the services are performed as } \\
\text { promised, including speed and accuracy) } \\
\text { Reliability and trustworthiness of service provider (the extent to which } \\
\text { promises are fulfilled) } \\
\text { - Item availability (the completeness of the content of the websites, as well as } \\
\text { the scope of the services offered) }\end{array}$ \\
\hline Convenience & 20.79 & The overall freedom from effort or from difficulty in using e-filing \\
\hline Efficiency & 12.46 & $\begin{array}{l}\text { The ease and speed of accessing and using the site, which includes the simplicity of } \\
\text { the structure and layout of the website }\end{array}$ \\
\hline System availability & 7.71 & The correct technical functioning of the site \\
\hline Reliability & 4.36 & The ability of SARS employees and systems to perform services accurately \\
\hline Assurance & 3.82 & $\begin{array}{l}\text { The knowledge and courtesy of employees and the ability of the content of the e- } \\
\text { service user-guide to convey trust }\end{array}$ \\
\hline Empathy & 1.26 & $\begin{array}{l}\text { The tax practitioners' sense that SARS's call centres are designed and operate so } \\
\text { that it is easy to gain access to the service }\end{array}$ \\
\hline Responsiveness & 0.93 & $\begin{array}{l}\text { The willingness (including the attentiveness) of employees, as well as the actual } \\
\text { timeliness or speed of services performed }\end{array}$ \\
\hline Security & 0.93 & $\begin{array}{l}\text { The protection of personal information relating to the taxpayer and the tax } \\
\text { practitioner }\end{array}$ \\
\hline Incentive & 0.39 & $\begin{array}{l}\text { The encouragement SARS acts as a motivation to use the e-services, namely by } \\
\text { indirectly assisting tax practitioners to overcome technology readiness barriers }\end{array}$ \\
\hline
\end{tabular}

The tax practitioners' view that the fulfilment service determinant $(31.31 \%)$ is the most important - with the efficiency service determinant (12.46\%) in third place - is in line with the findings of Lee and Lin (2005), Parasuraman et al. (2005), Wolfinbarger and Gilly (2003) and Yang et al. (2004).

Although the tax practitioners regarded the convenience service determinant as the second most important service determinant $(20.79 \%)$, its importance as a service determinant has not specifically been addressed in the literature. It is, however, recommended that convenience should be included as a service determinant in the e-service quality model, because convenience:

- $\quad$ directly affects perceptions of a firm's service quality (Berry et al., 2002);

- $\quad$ was also found to be relevant in other studies (Childers et al., 2001; Szymanski and Hise, 2000; Yang et al., 2004);

- $\quad$ is positively associated with website service quality (Zhang and Prybutok, 2005);

- $\quad$ was found to be crucial to taxpayers' decisions to use e-tax services (Hu et al., 2009); and

- $\quad$ is included in the most widely used e-service quality model (E-S-Qual developed by Parasuraman et al., 2005), and another service quality study of e-services in a tax agency environment (Connolly and Bannister, 2008).

The relatively low importance attached to the system availability determinant $(7.71 \%)$ is in line with the findings of Parasuraman et al. (2005:230). These authors found that system availability was an important contributor to customer perceptions of service quality, but not as important as efficiency and fulfilment. 
Although the reliability (4.36\%), assurance (3.82\%), empathy (1.26\%) and responsiveness $(0.93 \%)$ service determinants each received less than 5\% of the critical incidents, they all represent service determinants that are usually very important in the evaluation of traditional service quality. In an e-service quality environment these service determinants are also relevant. For example, tax practitioners would rely on a call centre if they require assistance with the e-services or in the case of e-service failures.

The security service determinant was awarded a very low number of critical incidents $(0.93 \%)$, probably because tax practitioners only face an indirect risk in using e-filing. The direct risk of using e-services is carried by the taxpayer. Nevertheless, it is proposed that the security service determinant should represent a service determinant on its own, because it may have a significant influence on customers' global evaluations of the service quality of e-services (Parasuraman et al., 2005; Rotchanakitumnuai, 2008); the critical incidents were reported mainly through the website, which may have contributed to an underestimation of the importance of the security determinant (Wolfinbarger and Gilly, 2003); and users of the e-services of SARS could be assumed to be frequent eservice users.

The incentive service determinant (SARS's encouragement to motivate the use of e-services, by indirectly assisting tax practitioners to overcome technological readiness barriers) attracted the lowest number of responses (only $0.39 \%$ ), but was included in the service quality framework, as Rotchanakitumnuai (2008) also found this aspect to be very relevant to a tax collection agency's e-service quality.

\subsection{Service dimensions}

The different service determinants were classified into the different e-service quality dimensions (level 3) identified by Parasuraman et al. (2005). Only three of the four dimensions identified by Parasuraman et al. (2005) being the normal operation dimension, the assistance dimension and the perceived value dimension - were relevant to this research. For the purpose of this study these dimensions were defined as presented in Table 3.

Table 3: Service dimensions for the 'lens of the tax practitioner'

\begin{tabular}{|l|l|l|}
\hline \multicolumn{1}{|c|}{ Dimension } & \multicolumn{1}{|c|}{ Number or responses } & \multicolumn{1}{c|}{ Definition } \\
\hline Normal operations dimension & $\begin{array}{l}879 \text { critical incidents } \\
68.46 \%\end{array}$ & $\begin{array}{l}\text { All the operational services that do not } \\
\text { form part of the assistance services or } \\
\text { perceived value aspects of SARS's } \\
\text { services in the proposed model }\end{array}$ \\
\hline Perceived value dimension & $\begin{array}{l}272 \text { critical incidents } \\
21.18 \%\end{array}$ & $\begin{array}{l}\text { The convenience and incentive benefits } \\
\text { of using e-filing }\end{array}$ \\
\hline Assistance dimension & $\begin{array}{l}133 \mathrm{critical} \text { incidents } \\
10.36 \%\end{array}$ & $\begin{array}{l}\text { The availability and efficiency of } \\
\text { assistance with e-services through the } \\
\text { telephone, online representatives and } \\
\text { electronic aids }\end{array}$ \\
\hline
\end{tabular}

Four different service determinants, namely fulfilment, efficiency, system availability and security, were clustered in the most important dimension, the normal operations services dimension (68.46\% of the responses).

Only two service determinants, namely the convenience and incentive service determinants, were classified under the perceived value dimension that is the second most important service dimension (21.18\%).

Only $10.36 \%$ of the responses related to the assistance dimension, which consisted of four service determinants: reliability, assurance, empathy and responsiveness. The results of this study as presented tend to underestimate the importance of the assistance dimension. The importance of this dimension should be evaluated against the background of the finding of Parasuraman et al. (2005) that respondents first have to encounter problems with using a website before they require assistance. Rotchanakitumnuai (2008) also included this aspect as a dimension called 'customer support'.

It is clear that the results of this study as presented acknowledges three service quality dimensions, but Parasuraman et al. (2005) found that it is advisable to use four different dimensions in measuring the service quality 
of e-services in their E-S-Qual model - normal operations, assistance (referred to as recovery situations), perceived value and loyalty intentions. The loyalty dimension was not relevant for building the 'lens of the tax practitioner'. It could be argued that a revenue authority does not have any competitor to which tax practitioners could migrate. Closer analysis of this loyalty dimension, however, indicates that it could also refer to the loyalty of using e-services of a particular service provider as opposed to the traditional services. No critical incident reported by the tax practitioners referred to any loyalty aspects and this dimension was therefore not included in the proposed service quality framework.

The existence of only three service quality dimensions in this study supports the results of a study by Boshoff (2007), who found that the E-S-Qual's four-dimensional configuration is not necessarily valid for all service settings.

\subsection{The e-service quality framework}

The 'lens of the tax practitioner' encompasses the different service attributes, service determinants and service dimensions that are relevant in tax practitioners' evaluation of the e-service quality of a revenue agency (SARS). It is presented as a proposed e-service quality framework in Table 4.

Table 4: Service quality framework encapsulating the e-service 'lens of the tax practitioner'

\begin{tabular}{|c|c|}
\hline \multicolumn{2}{|c|}{ Normal Operations Service Quality Dimension } \\
\hline Service determinant & Service attribute \\
\hline Fulfilment & $\begin{array}{l}\text { - Scope of services offered } \\
0 \quad \text { Scope of services offered through e-filing } \\
0 \quad \text { Completeness of the website } \\
\text { Speed of service performance } \\
\circ \quad \text { Turnaround time } \\
\circ \quad \text { Timeliness of updates } \\
\text { - } \quad \text { Accurate service delivery }\end{array}$ \\
\hline Efficiency & $\begin{array}{ll}- & \text { Ease of use } \\
& \text { Organisation } \\
- & \text { Speed of launching the site and pages } \\
& \text { Ease of finding information }\end{array}$ \\
\hline System availability & $\begin{array}{ll}- & \text { Pre-testing } \\
- & \text { Crash and freeze problems } \\
\end{array}$ \\
\hline Security & $\begin{array}{ll}- & \text { Protection of personal information } \\
\text { - } & \text { Protection of personal liability of tax practitioner }\end{array}$ \\
\hline \multicolumn{2}{|c|}{ Perceived Value Dimension } \\
\hline Service determinant & Service attribute \\
\hline Convenience & $\begin{array}{ll}- & \text { Time saving } \\
\text { - } & \text { Electronic filing system } \\
\text { - } & \text { Reduction of effort } \\
\text { - } & \text { When I want it } \\
\text { - } & \text { Cost saving } \\
\text { - } & \text { Where I want it }\end{array}$ \\
\hline Incentive & Incentive \\
\hline \multicolumn{2}{|l|}{ Assistance Dimension } \\
\hline Service determinant & Service attribute \\
\hline Reliability & - $\quad$ Accurate service delivery \\
\hline Assurance & Knowledge and skills of employees \\
\hline Empathy & - $\quad$ Waiting time \\
\hline Responsiveness & $\begin{array}{ll}- & \text { Speed of performing the service } \\
\text { - } & \text { Willingness of employees } \\
\end{array}$ \\
\hline
\end{tabular}

Although the present research serves as the first groundbreaking step in the development of an e-service quality framework for SARS, the results provide only a theoretical framework for the evaluation of the e-service 
quality as perceived by tax practitioners. Further research is needed to develop the measuring instrument itself and to design items, questions or statements to encapsulate these service determinants and service attributes and to develop rating scales and the relevant instructions. A reliable and concise measuring instrument is needed to enable SARS (or any independent third party) to conduct research into the quality of its e-services to tax practitioners.

It should be remembered that different stakeholders tend to evaluate services on different levels (Nomdoe and Pather, 2007). As the framework proposed in the present research is based on the 'lens of the tax practitioner', representing only one stakeholder among many in SARS, it is possible that the framework will require adjustment if the service quality is evaluated from the perspective(s) of other stakeholders (for example, the taxpayers). The framework should thus be validated using a test population from another stakeholder group before it can be applied to measure the service quality of SARS from that stakeholder's perspective.

\section{CONCLUSION}

Tax revenue forms the backbone of the South African economy. This underlines the need to enhance taxpayer compliance. The quality of the e-services provided by SARS is crucial, as e-service quality directly influences the burden of complying with tax obligations, and hence directly affects the tax compliance climate in a country.

The aim of this research was to develop an e-service quality framework that encapsulates the 'lens of the tax practitioner'. This research is the first qualitative study designed to build the 'lens of the tax practitioner' in evaluating the e-service quality of a revenue agency in an African context. With regard to the research on the eservice quality of SARS, the present research provides a basis for other researchers and may also stimulate the momentum of e-service quality research in the tax agency environment. It is hoped that in the not-too-far future the world will not only experience peace in the Middle East, but also receive high quality e-services from their revenue authorities.

\section{ACKNOWLEDGMENTS}

The National Research Foundation (NRF) provided me with financial assistance to execute the research as published in this article.

\section{AUTHOR INFORMATION}

Madeleine Stiglingh, Ph.D., CA, SA is the departmental head of the Department of Taxation at the University of Pretoria, South Africa. Apart from managerial and lecturing responsibilities, she acts as study leader for post graduate students, publishes articles in accredited, refereed and other journals, both nationally and internationally and is the editor of the most widely used taxation textbook, Silke on South African Income Tax. Prof Stiglingh frequently presents taxation related papers at various conferences, both nationally and internationally. E-mail: Madeleine.Stiglingh@up.ac.za

\section{REFERENCES}

1. Arkinci, S., Atilgan-Inan, E. and Aksoy, S. (2010). Re-assessment of E-S-Qual and E-RecS-Qual in a pure service setting. Journal of Business Research, 63(3), March: 232-240.

2. Barnes, S. and Vidgen, R. (2007). Interactive e-government: Evaluating the web site of the UK Inland Revenue. Journal of Electronic Government Research, 3(1), 19-37.

3. Berry, L.L., Zeithaml, A. and Parasuraman, A. (1985). Quality counts in services, too. Business Horizons, May/June: 44-52.

4. Berry, L.L., Parasuraman, A. and Zeithaml, V.A. (1988). The service-quality puzzle. Business Horizons, 31(5), September/October: 35-43.

5. Berry, L.L., Seiders, K. and Grewal, D. (2002). Understanding service convenience. Journal of Marketing, 66:1-17. 
6. Bitner, M.J. (1990). Evaluating service encounters: the effects of physical surroundings and employee responses. Journal of Marketing, 54:69-82.

7. Boothe, R. (1990). Who defines quality in service industries. Quality Progress, February: 65-67.

8. Boshoff, C. (2007). A psychometric assessment of E-S-Qual: a scale to measure electronic service quality. Journal of Electronic Commerce Research, 8(1): 101-114.

9. Buckley, J. (2003). E-service quality and the public sector. Managing Service Quality, 13(6): 453-462.

10. Childers, T.L., Carr, C.L., Peck, J. and Carson, S. (2001). Hedonic and utilitarian motivations for online retail shopping behaviour. Journal of Retailing, 77: 511-535.

11. Christobal, E., Flavian, C. and Guinaliu, M. (2007). Perceived e-service quality (PeSQ). Managing Service Quality, 17(3): 317-340.

12. Connolly, R. and Bannister, F. (2008). eTax Filing \& Service Quality: The case of the revenue online service. Proceedings of World Academy of Science, Engineering and Technology, 48 (April): 313-317.

13. Cox, J., Dale, B.G. (2001). Service quality and e-commerce: an exploratory analysis. Managing Service Quality, 11, 2; ABI/INFORM Complete.

14. Croome, B. (2006). High expectations from SARS charter. RealBusiness[net]work. Retrieved from: http://www.realbusiness.co.za/Article.aspx?articleID $=3615$

15. Dabholkar, P.A., Shepherd, C.D. and Thorpe I.T. (2000). A comprehensive framework for service quality: an investigation of critical conceptual and measurement issues through a longitudinal study. Journal of Retailing, 76(2): 139-173.

16. Donnelly, M. and Shiu, E. (1999). Assessing service quality and its link with value for money in a UK local authority's housing repair service using the SERVQUAL approach. Total Quality Management, 10(4\&5): 598-506.

17. Flanagan, J.C. (1954). The critical incident technique. Psychological Bulletin, 51(4), July: 1-33.

18. Garvin, D.A. (1984). What does "Product Quality" really mean? Sloan Management Review, 26(1), Fall: 25-40.

19. Gaster, L. and Squires, A. (2003). Providing quality in the public sector: a practical approach to improving public services. Maidenhead, PA: Open University Press.

20. Gremler, D.D. (2004). The critical incident technique in service research. Journal of Service Research, 7(1), August: $65-89$.

21. Grönroos, C. (1984), A service quality model and its marketing implications. European Journal of Marketing, 18(4): 36-44.

22. Grönroos, C. (1988). Service quality: the six criteria of good perceived service quality. Review of Business, 9(3), Winter: 10-13.

23. Gummesson, E. (1992). Quality dimensions: What to measure in service organizations. In: Swartz, T.A., Bowen, D.E. and Brown, S.W. (eds). Advances in service marketing and management: Research and practice (pp. 177-205). London: Jai.

24. Hu, P.J., Brown, S.A., Thong, J. Y. L., Chan, F. K. Y. and Tam, K.Y. (2009). Determinants of service quality and continuance intentions of online services: The case of eTax. Journal of the American Society for Information Science and Technology, 60(2): 292-306.

25. Hwang, C.S. (2000). A comparative study of tax-filing methods: Manual, Internet, and two-dimensional bar code. Journal of Government Information, 27: 113-127.

26. Johnson, M.D. and Gustafsson, A. (2000). Improving customer satisfaction, loyalty and profit - An integrated measurement and management system. San Francisco: Jossey-Bass.

27. Juran, J.M. (1988). Juran on planning for quality. New York: Free Press.

28. Kang, G. and James, J. (2004). Service quality dimensions: an examination of Grönroos's service quality model. Managing Service Quality, 14(4): 266-277.

29. Ladhari, R. (2010). Developing e-service quality scales: A literature review. Journal of Retailing and Consumer Services, doi:10.1016/j.jretconser.2010.06.003, 1-14.

30. Lee, G.G. and Lin, J.F. (2005). Customer perceptions of e-service quality in online shopping. International Journal of Retail \& Distribution Management, 33(22): 161-176.

31. Lind, M., Forsgren, N.S., Salomonson, N. and Albinsson, L. (2007). The E-CO model - citizens' driving eservice quality. Paper presented at the $51^{\text {st }}$ Annual Conference of the International Society for the Systems Sciences (ISSS), 5 - 10 August, Tokyo, Japan. 
32. Madu, C.N. and Madu, A.A. (2002). Dimensions of e-quality. International Journal of Quality \& Reliability Management, 19(3): 246-258.

33. Magashula, O. (2010). Address by Commissioner of the South African Revenue Service Mr Oupa Magashula to the Ernst \& Young Africa Tax Conference 2010. 20 September 2010. Retrieved from: www.sars.gov.za/tools/Printbody.asp?pid=63144

34. Nomdoe, H. and Pather, S. (2007). Providing a holistic perspective to evaluating e-service quality in webbased systems: a multi-stakeholder approach. ACM International Conference Proceeding Series, 226: 97 105 .

35. Oberholzer, R. (2008). Perceptions of taxation: a comparative study of different population groups in South Africa. Unpublished DCom thesis, Pretoria: University of Pretoria.

36. Odekerken-Schröder, G., Van Birgelen, M., Lemmink, J., De Ruyter, K. and Wetzels, M. (2000). Moments of sorrow and joy: An empirical assessment of the complementary value of critical incidents in understanding customer service evaluations. European Journal of Marketing, 34(1/2): 107-125.

37. OECD (2008). Study into the role of tax intermediaries. Forum on tax administration. January 2008. Retrieved from: www.oecd.org/dataoecd/28/34/39882938.pdf

38. OECD (2010a). Sixth Meeting of the OECD Forum on Tax Administration. Forum on Tax Administration, 15-16 September 2010, Istanbul.

39. OECD (2011). Members and partners. Retrieved from:

40. http://www.oecd.org/pages/0,3417,en_36734052_36761800_1_1_1_1_1,00.html

41. Palfrey, C., Phillips, C., Thomas, P. and Edwards, D. (1992). Policy evaluation in the public sector approaches and methods. Brookfield, VT: Ashgate.

42. Parasuraman, A., Zeithaml, V.A. and Berry, L.L. (1985). A conceptual model of service quality and its implications for future research. Journal of Marketing, 49: 41-50.

43. Parasuraman, A., Zeithaml, V. and Berry, L.L. (1986). Servqual: A multiple-item scale for measuring customer perceptions of service quality. Cambridge, MA: Cambridge Marketing Science Institute.

44. Parasuraman, A., Zeithaml, V.A. and Berry, L.L. (1988). SERVQUAL: A multiple-item scale for measuring consumer perceptions of service quality. Journal of Retailing, 64(1), Spring: 12-40.

45. Parasuraman, A., Berry, L.L. and Zeithaml, V. (1991). Refinement and reassessment of the SERVQUAL scale. Journal of Retailing, 67(4), Winter: 420-451.

46. Parasuraman, A., Zeithaml, V.A. and Malhotra, A. (2005). E-S-QUAL - a multiple-item scale for assessing electronic service quality. Journal of Service Research, 7(3), February: 213-233.

47. Philip, G. and Hazlett, S. (1997). The measurement of service quality: a new P-C-P attributes model. International Journal of Quality \& Reliability Management, 14(3): 260-286.

48. Philip, G. and Stewart, J. (1999). Assessment of the service quality of a cancer information service using a new P-C-P attributes model. Managing Service Quality, 9(3): 167-179.

49. Robledo, M.A. (2001). Measuring and managing service quality: integrating customer expectation. Managing Service Quality, Vol. 1, Iss 1, 22-31.

50. Rotchanakitumnuai, S. (2008). Measuring e-government service value with the E-GOVSQUAL-RISK model. Business Process Management Journal, 14(5), 724-737.

51. Santos, J. (2003). E-service quality: a model of virtual service quality dimensions. Managing Service Quality, 13(3): 233-246.

52. SARS Practitioners Unit. (2007). Filing Season 2007. Practitioner News, Issue 1, 10 May. Retrieved from: http://www.sarsefiling.co.za/Filing2007/Filing2007_TaxPrac_Issue1.html

53. SARS. (2010a). Annual Report 2008/2009. Retrieved from: http://www.sars.gov.za/home.asp?pid=286

54. SARS. (2010b). SARS strategic plan 2010/2011 - 2012/2013. Retrieved from: http://www.sars.gov.za/home.asp?pid=286

55. Schneider, B. and White, S.S. (2004). Service quality: Research Perspectives. Thousand Oaks, CA: Sage.

56. Seth, N., Deshmukh, S.G. and Vrat, P. (2005). Service quality models: a review. International Journal of Quality \& Reliability Management, 22(9): 913-949.

57. $\quad$ Snyckers, T. (2006). Practitioners: Current state assessment. Pretoria: SARS.

58. Stiglingh, M. (2009) Developing a model to evaluate the quality of the services rendered by the South African Revenue Service. Unpublished DCom thesis, Pretoria: University of Pretoria.

59. Szymanski, D.M. and Hise, R.T. (2000). e-Satisfaction: An initial examination. Journal of Retailing, 76(3): 309-322. 
60. Vos, C.A. (2003). Rethinking paradigms of service - service in a virtual environment. International Journal of Operations \& Production Management, 23(1): 88-104.

61. Wolfinbarger, M., and Gilly, M.C. (2003). eTailQ: dimensionalizing, measuring and predicting retail quality. Journal of Retailing, 79(3): 183-198.

62. Yang, A., Jun, M. and Peterson, T. R. (2004). Measuring customer perceived online service quality. International Journal of Operations \& Production Management, 24(11): 1149-1174.

63. Zeithaml, V.A., Parasuraman, A. and Malhotra A. (2002). Service quality delivery through web sites: a critical review of extant knowledge. Journal of the Academy of Marketing Science, 30(4): 362-375.

64. Zhang, X. and Prybutok,V.R. (2005). A consumer perspective of e-service quality. IEEE Transactions on Engineering Management, 52(4): 461-477.

65. Zhu, F.X., Wymer, W. (Jr) and Chen, I. (2002). IT-based services and service quality in consumer banking. International Journal of Service Industry Management, 13(1): 69-90. 
NOTES 